\title{
Effects of different recruitment maneuvers on bacterial translocation and ventilator-induced lung injury
}

\author{
Perihan Ergin Özcan, M.D., ${ }^{1}$ Özkan İbrahim Akıncı, M.D., ${ }^{1}$ İpek Edipoğlu, M.D., ${ }^{1}$ \\ Evren Şentürk, M.D., ${ }^{1}$ Sevil Baylan, M.D., ${ }^{1}$ Atahan Arif Cağatay, M.D., ${ }^{2}$ \\ Kemal H Türköz, M.D., ${ }^{3}$ Figen Esen, M.D., ${ }^{1}$ Lütfi Telci, M.D., ${ }^{1}$ Nahit Çakar, M.D. ${ }^{1}$ \\ ${ }^{1}$ Department of Anesthesiology, İstanbul University İstanbul Faculty of Medicine, İstanbul-Turkey \\ ${ }^{2}$ Department of Infectious Diseases and Clinical Microbiology, İstanbul University İstanbul Faculty of Medicine, İstanbul-Turkey \\ ${ }^{3}$ Department of Pathology, Marmara University Faculty of Medicine, Istanbul-Turkey
}

\begin{abstract}
BACKGROUND: Investigated in the present study were the effects of various recruitment maneuvers (RMs) using the same inflation pressure-time product on bacterial translocation from lung to blood, and ventilator-induced lung injury (VILI).

METHODS: Tracheotomy was performed on anesthetized rats, and ventilation was initiated using pressure-controlled mode. Subsequently, Pseudomonas aeruginosa was inoculated through the tracheotomy tube and ventilated for 30 minutes before rats were randomly separated into 4 groups. Group I underwent sustained inflation (SI), Group 2 underwent low-pressure SI, Group 3 underwent modified sigh, and Group 4 was a control group. Blood cultures were taken at baseline, 15 minutes after randomization (after each RM for the first hour), and finally at 75 minutes after the last RM. The rats were euthanized and the lungs were extirpated. The left lung was taken for measurement of wet:dry weight ratio, and the right lung was used for pathologic evaluation.
\end{abstract}

RESULTS: Positive blood cultures were found to be higher in Group 3 at early study periods. Total pathological scores were also higher in Group 3.

CONCLUSION: Higher severity of ventilator-induced lung injury occurred in the modified sigh group, evidenced by bacterial translocation and results of histopathological evaluation.

Keywords: Bacterial translocation; mechanical ventilation; recruitment maneuver; SIGH; ventilator-induced lung injury.

\section{INTRODUCTION}

Mechanical ventilation is the most important supportive therapeutic option in cases of acute respiratory distress syndrome (ARDS). However, it is well known, based on experimental and human studies, that mechanical ventilation may cause ventilator-induced lung injury (VILI). ${ }^{[1]}$

Different recruitment maneuvers (RMs) are important adjuncts of mechanical ventilation in clinical practice, used to

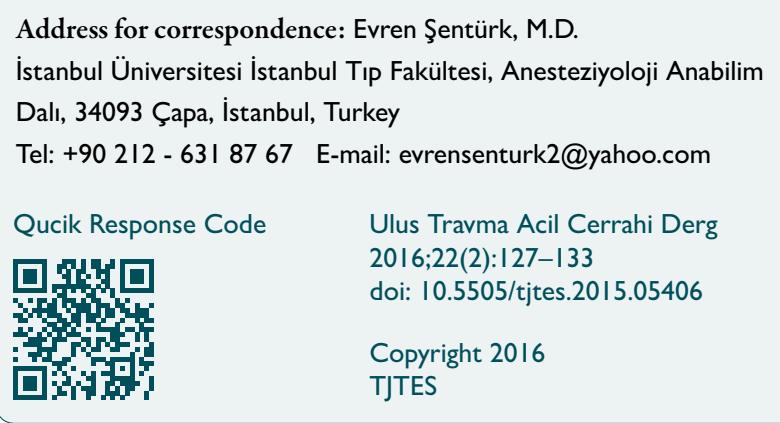

enhance oxygenation by opening collapsed sections of the lung. Due to the tendency of unstable alveoli to collapse, it is thought that RMs are likely to reduce VILI that occurs due to repeated opening and closing during ventilation. However, RMs have side effects, and may induce hyperinflation and lung injury. ${ }^{[2]}$ Therefore, to evaluate RMs for efficiency and related risks, optimal pressure level, applicable time period, and applicable rate should be discussed.

RMs can be performed in different ways. Sustained inflation (SI) is applied to raise static airway pressure to a fixed level for a fixed time period. Inflation pressure applied in several RM-related studies has ranged between 30 and $60 \mathrm{cmH}_{2} \mathrm{O}$, with the time periods ranging from 3 seconds to 3 minutes. These studies have suggested that the magnitude of airway pressure and duration of pressure elevation play major roles in the success of an RM. ${ }^{[3-5]}$ Respiratory effects of different RMs have also been studied. ${ }^{[6]}$

Bacterial translocation from the lungs to the bloodstream has been used as a marker of VILI in a number of experimental 
studies. ${ }^{[7-10]}$ Repeated collapse and reopening of the alveoli, inflammation, and high ventilation pressures and volumes have been shown to cause VILI. ${ }^{[1,12]}$

Examined in the present study were the effects of different RMs with identical inflation pressure-time products on bacterial translocation from the lungs to the bloodstream, oxygenation, morphologic changes, and wet:dry weight ratio of the lungs. The authors hypothesized that the level of pressure applied was not the only factor triggering VILI, and that the frequency and timing of pressure also had significant impacts on its occurrence.

\section{MATERIALS AND METHODS}

The study was conducted following approval of protocol from the Institutional Animal Investigation Committee. Care and handling of the animals were in accordance with European Community guidelines. Thirty-two male Sprague Dawley rats (each weighing 250-300 g) were used. Sample size was calculated in accordance with a previous study. ${ }^{[10]}$ Significance level of $5 \%(\alpha=0.05)$ and probability of $80 \%(\beta=0.20)$, used to detect a difference of at least $80 \%$ increase in bacterial translocation, indicated an appropriate sample size of $n=7$ subjects.

\section{Animal Preparation}

Rats were anesthetized with inhaled mixture of $\mathrm{I}-3 \%$ isoflurane, $60 \% \mathrm{O}_{2}$, and $40 \%$ air, with subsequent intraperitoneal injection of $50 \mathrm{mg} / \mathrm{kg}$ ketamine. Following surgical tracheotomy, the rats were kept under pressure-controlled ventilation with Servo 300 ventilator (Siemens AG, Solna, Sweden).

Ventilation parameters:

(i) peak inspiratory pressure (PIP) of $10 \mathrm{cmH}_{2} \mathrm{O}$

(ii) positive end-expiratory pressure (PEEP) of $0 \mathrm{cmH}_{2} \mathrm{O}$

(iii) respiratory rate of 60 breaths/minute

(iv) inspired fraction of oxygen $\left(\mathrm{FiO}_{2}\right)$ of $\mathrm{I} .0$

(v) inspiratory-to-expiratory time ratio $(\mathrm{I} / \mathrm{E})$ of $\mathrm{I} / 2$

Intraperitoneal ketamine $(50 \mathrm{mg} / \mathrm{kg}$ ) and vecuronium bromide $(0.5 \mathrm{mg} / \mathrm{kg})$ were also used for maintenance of anesthesia and muscle relaxation.

The carotid artery was cannulated using 24-gauge Insyte-W catheter (Becton Dickinson Infusion Therapy Systems Inc., Sandy, UT, USA) in aseptic conditions. Blood pressure was monitored using Mercury disposable transducer (Mennen Medical, Inc., Southampton, PA, USA), and blood samples were obtained for blood gas analyses and blood cultures. Rectal body temperatures were continuously monitored, and normothermia was maintained using heating lamp and pad.

\section{Bacterial Preparation}

Regarding preparation of the bacterial solution, Pseudomonas aeruginosa (ATCC 27853) were thawed and cultured over- night, incubated in brain-heart infusion broth (Becton Dickinson Diagnostics, Inc., Sparks, MD, USA) in $37^{\circ} \mathrm{C}$ to obtain stationary-phase microorganisms. A tube containing an inoculum of $1 \times 10^{5}$ colony-forming units $/ \mathrm{mL}$ of Pseudomonas aeruginosa was individually prepared for each rat on every study day and kept on ice until used.

\section{Experiment Protocol}

After completion of monitorization, rats were ventilated with baseline ventilator settings for 15 minutes in order to achieve stabilization. Baseline ventilator parameters (tidal volume $\left[\mathrm{V}_{\mathrm{T}}\right]$, PIP, mean airway pressure [MawP], PEEP) and hemodynamic parameters (mean arterial pressure [MAP], heart rate $[H R]$ ) were recorded. Blood samples were obtained for baseline blood gas analyses and blood culture. Colloid solution (hydroxyethyl starch 450/0.7, 6\%; Eczacıbaşı Baxter, İstanbul, Turkey) was infused to replace blood loss after each blood draw. Blood pressure was kept within normal range by saline infusion.

After first blood samples were obtained, $500 \mu \mathrm{L}$ of saline containing $10^{5} \mathrm{cfu} / \mathrm{mL}$ Pseudomonas aeruginosa was instilled through the tracheostomy tube, and $5 \mathrm{~mL}$ of air was injected to distribute the bacteria through the lungs.

PEEP level was increased to $3 \mathrm{cmH}_{2} \mathrm{O}$, and all rats were ventilated for 30 minutes prior to being randomly separated into 4 groups, as follows:

- Group I (Pressure group): SI of $40 \mathrm{cmH}_{2} \mathrm{O}$ PEEP - $20 \mathrm{sec}$, 4 times/h

- Group 2 (Time group): Low-pressure $\mathrm{SI}$ of $20 \mathrm{cmH}_{2} \mathrm{O}$ PEEP - $40 \mathrm{sec}, 4$ times/h

- Group 3 (Modified sigh group): Modified sigh of $40 \mathrm{~cm}$ $\mathrm{H}_{2} \mathrm{O}$ PIP - $3 \mathrm{cmH}_{2} \mathrm{O}$ PEEP for I minute, f: $60 /$ minute, I/E:I/2, 4 times/h

- Group 4 (Control group): $10 \mathrm{cmH}_{2} \mathrm{O}$ PIP - $3 \mathrm{cmH}_{2} \mathrm{O}$ PEEP

In all groups, ventilator settings between RMs were maintained at baseline (PIP: $10 \mathrm{cmH}_{2} \mathrm{O}$; PEEP: $3 \mathrm{cmH}_{2} \mathrm{O}$; f:60/min; $\left.\mathrm{FiO}_{2}: \% 100 ; \mathrm{I} / \mathrm{E}: \mathrm{I} / 2\right)$.

Inflating pressure-time product (the product of the pressure value over the time it is applied) was equal in the 3 RMs (Fig. I). The method applied in Group 3 was not completely in line with sigh. For this reason, in order to establish an equal product in all groups, high PIP $\left(40 \mathrm{cmH}_{2} \mathrm{O}\right)$ was imposed at a frequency level of $60 /$ minute for I minute. Because of this, the RM of Group 3 is described as "modified sigh."

\section{Microbiologic Evaluation}

Blood cultures were incubated at $37^{\circ} \mathrm{C}$ overnight and kept in the incubator for at least 10 days. Blood cultures were analyzed to determine whether culture positivity had been obtained each day, regardless of turbidity or opacity. Bacteremia was defined as $\geq 1$ colony of Pseudomonas aeruginosa appearing in $100 \mu \mathrm{L}$ of blood sample cultured on agar plate. 


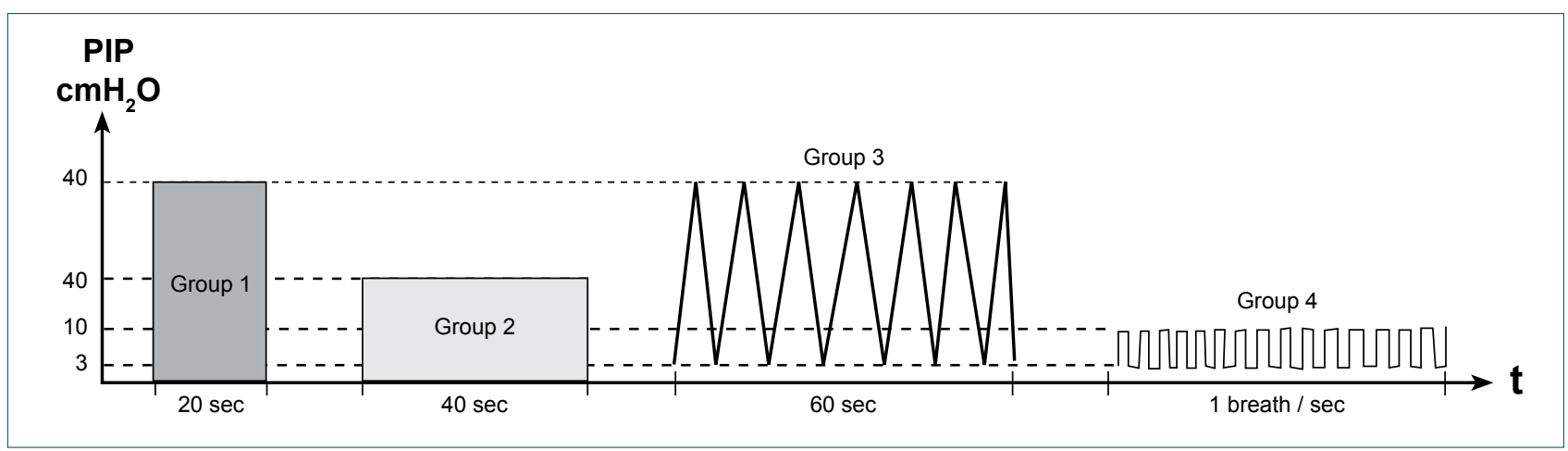

Figure 1. Inflation pressure-time product of groups.

Group 1 (Pressure) $=40 \mathrm{cmH}_{2} \mathrm{O} \times 20 \mathrm{sec} \times 4$ times/h= 3200 inflation pressure-time product

Group 2 (Time) $=20 \mathrm{cmH}_{2} \mathrm{O} \times 40 \mathrm{sec} \times 4$ times/h= 3200 inflation pressure-time product

Group 3 (Modified sigh) $=40 \mathrm{cmH}_{2} \mathrm{O} \times 20 \mathrm{sec} \times 4$ times/h= 3200 inflation pressure-time product (f:60/min, l/E: $1 / 2$, inspiratory time period 20 sec in each sigh) Group 4 (Control group)

Isolated strains were identified using standard microbiological methods. Pseudomonas aeruginosa strains were identified by the presence of large colonies, grape-like odor, oxidasepositive colonies, the ability to grow at $42^{\circ} \mathrm{C}$, and characteristic pigmentation. Once isolated strains were identified, E-test strips (AB Biodisk Na Inc., Solna, Sweden) were used to determine whether susceptibility pattern was similar to that of Pseudomonas aeruginosa.

\section{Morphological Evaluation}

The rats were euthanized using intra-arterial sodium thiopental ( $120 \mathrm{mg} / \mathrm{kg})$, the thorax was opened under aseptic conditions, and the lungs were extirpated with the heart. The left lung was used for the measurement of wet:dry weight. Microbalances were used to determine wet weight; the lung was then kept in an incubator at $100^{\circ} \mathrm{C}$ for 24 hours and weighed again to determine dry weight.

The right lung was sent to the pathology laboratory in $10 \%$ formalin. A pathologist blinded to the study groups performed histological examination. The lung was serially sectioned in caudal-to-coronal fashion from the apex to the base and embedded in paraffin blocks. Following routine dehydration and clearing processes, 3-4 $\mu$ m sections from each paraffin block were taken and stained with hematoxylin and eosin. All fields of slides were read. Sections were evaluated with grading scale of 0 to 3 for 6 parameters (perivascular edema, peribronchial lymphocytic infiltration, intra-alveolar hemorrhage, intra-alveolar macrophage infiltration, interstitial mononuclear cell infiltration, interstitial polymorphonuclear leukocyte infiltration; 0 = none, $\mathrm{I}=$ focal and rare, 2 = widespread, 3 = whole-lung involvement).

Six blood cultures were taken: at baseline, 15 minutes after RM, and 75 minutes after final maneuver. In addition, ventilator variables and hemodynamic parameters were recorded simultaneously. Blood gas analyses were performed at baseline and at experiment conclusion, when the final blood culture was taken. Schematic diagram of the experiment is shown in Fig. 2. Primary outcome was evaluation of bacterial translocation, and secondary outcomes concerned oxygenation, morphologic changes, and wet:dry weight.

\section{Statistical Analysis}

Morphologic evaluation scores, and $\mathrm{pH}, \mathrm{PaO}_{2}, \mathrm{PaCO}_{2}, \mathrm{MawP}$, and MAP values are reported as mean $\pm \mathrm{SD}$. Intergroup comparisons were performed using Kruskal-Wallis one-way analysis of variance. Dunn's multiple comparisons test was used for post-hoc analysis when $p<0.05$. Wilcoxon Mann-Whitney $U$ test was used for intragroup analysis. Chi-square test was used to compare positive blood cultures among groups. Kaplan-Meier curves and log-rank test were used to analyze bacterial translocation. In all analyses, $\mathrm{p}<0.05$ was considered statistically significant.

Induction of anesthesia $P$. aeruginosa

Figure 2. Schematic diagram of experimental protocol. 


\section{RESULTS}

\section{Blood Cultures}

All rats survived until the end of the experiment. Positive blood cultures were observed 15 minutes after the first maneuver in I rat Group I, 2 rats in Group 2, and 5 rats in Group 3 (Table I). In Group 3, positive blood cultures were observed in all rats after the third maneuver. Group 4 and Group 3 culture results differed at all times except baseline. Blood culture results obtained following third RM revealed that the number of positive cultures in Group 3 was significantly different than in Group 2 (OR: 0.02; 95\% Cl: 0.0009 to $0.55, p=0.007$ ) and Group 4 (OR: $0.003 ; 95 \% \mathrm{Cl}: 0.0000$ to $0.19, p=0.0002$ ). By the end of the experiment, all blood cultures were positive in Groups I, 2, and 3, but no positive blood cultures were present in Group 4. In Fig. 3, the KaplanMeier curve shows percentage of positive blood cultures in terms of time in each group ( $p=0.0012$, log-rank test).

Blood Gas Analysis, and Hemodynamic and Mechanical Ventilation Variables

Baseline $\mathrm{pH}, \mathrm{PaO}_{2}, \mathrm{PaCO}_{2}$, MawP, and MAP were similar in all groups (Table 2). When baseline and end-of-experiment values were compared, $\mathrm{PaO}_{2}$ was lower in Groups I, 2, and 3, though the difference was significant only in Group $3(p=0.004)$. By the end of the experiment, the $\mathrm{PaO}_{2}$ value in Group 4 was significantly higher than that in Groups I, 2, and 3 . In addition, $\mathrm{PaCO}_{2}$ was decreased in all experimental groups. However, no significant differences between baseline and final $\mathrm{PaCO}_{2}$ values were observed.

Table I. Time course of positive blood culture results

\begin{tabular}{lcccccc}
\hline & Baseline & I $^{\text {st }}$ RM & 2 $^{\text {nd }} \mathbf{R M}$ & 3 $^{\text {rd }}$ RM & 4 $^{\text {th }}$ RM & 75 min after last RM \\
\hline Group I $(n=8)$ & 0 & 1 & 4 & 6 & 8 & 8 \\
Group 2 $(n=8)$ & 0 & 2 & 2 & $2^{\dagger}$ & 5 & 8 \\
Group 3 $(n=8)$ & 0 & 5 & 6 & 8 & 8 & 8 \\
Group 4 $(n=8)$ & 0 & $0^{*}$ & $0^{*}$ & $0^{\dagger \neq}$ & $0^{\S}$ & 0 \\
\hline
\end{tabular}

RM: Recruitment maneuver. " $p<0.05$, significantly different from Group $3 ;{ }^{\dagger} p<0.05$, significantly different from Group 3 ; ${ }^{*} p<0.05$, significantly different from Group I; ${ }^{\S} \mathrm{p}<0.05$, significantly different from Groups 1,2 , and 3 .

Table 2. Oxygenation, and hemodynamic and mechanical ventilation variables

\begin{tabular}{|c|c|c|c|c|}
\hline & Group I & Group 2 & Group 3 & Group 4 \\
\hline \multicolumn{5}{|l|}{$\mathrm{pH}$} \\
\hline Baseline & $7.42 \pm 0.05$ & $7.4 I \pm 0.04$ & $7.4 I \pm 0.03$ & $7.4 I \pm 0.02$ \\
\hline End of experiment & $7.45 \pm 0.04^{*}$ & $7.44 \pm 0.004$ & $7.38 \pm 0.05$ & $7.4 I \pm 0.03$ \\
\hline \multicolumn{5}{|l|}{$\mathrm{PaO}_{2}(\mathrm{mmHg})$} \\
\hline Baseline & $263.12 \pm 130$ & $221.0 \pm 40.5$ & $243.0 \pm 50.7$ & $254.0 \pm 31.8$ \\
\hline End of experiment & $226.7 \pm 6 I^{*}$ & $189.0 \pm 55.8^{*}$ & $166.6 \pm 30.2^{* \dagger}$ & $310.0 \pm 51.4$ \\
\hline \multicolumn{5}{|l|}{$\mathrm{PaCO}_{2}(\mathrm{mmHg})$} \\
\hline Baseline & $36.2 \pm 6.3$ & $35.2 \pm 3.8$ & $32.2 \pm 4.6$ & $32.1 \pm 4.8$ \\
\hline End of experiment & $32.2 \pm 6.2$ & $31.9 \pm 3.2$ & $30.3 \pm 4.5$ & $29.0 \pm 2.8$ \\
\hline \multicolumn{5}{|l|}{ MAP $(\mathrm{mmHg})$} \\
\hline Baseline & $96.2 \pm 8.3$ & $94.0 \pm 16.2$ & $90.6 \pm 7.5$ & $91.5 \pm 12.9$ \\
\hline End of experiment & $60.2 \pm 8.5^{*}+$ & $61.6 \pm 12.4^{*+}$ & $53.6 \pm 8 . I^{*+}$ & $80.6 \pm 8.8$ \\
\hline \multicolumn{5}{|l|}{$\operatorname{MawP}\left(\mathrm{cmH}_{2} \mathrm{O}\right)$} \\
\hline Baseline & $4.8 \pm 0.6$ & $4.5 \pm 1.2$ & $4.4 \pm 1.6$ & $4.1 \pm 0.7$ \\
\hline End of experiment & $5.6 \pm 0.6$ & $5.6 \pm 0.7$ & $5.7 \pm 0.6$ & $5.3 \pm 1.2$ \\
\hline \multicolumn{5}{|l|}{ VT (mL) } \\
\hline Baseline & $8.12 \pm 1.2$ & $8.0 \pm 1.3$ & $8.12 \pm 1.5$ & $8.8 \pm 0.8$ \\
\hline End of experiment & $8.8 \pm 0.8$ & $8.6 \pm 0.7$ & $8.3 \pm 1.8$ & $8.1 \pm 1.1$ \\
\hline
\end{tabular}

MAP: Mean arterial pressure; MawP: Mean airway pressure; $\mathrm{V}_{\mathrm{T}}$ : Tidal volume. ${ }^{*} \mathrm{p}<0.05$, significantly different from Group 4 ; ${ }^{\dagger} \mathrm{p}<0.005$, significantly different from baseline. 


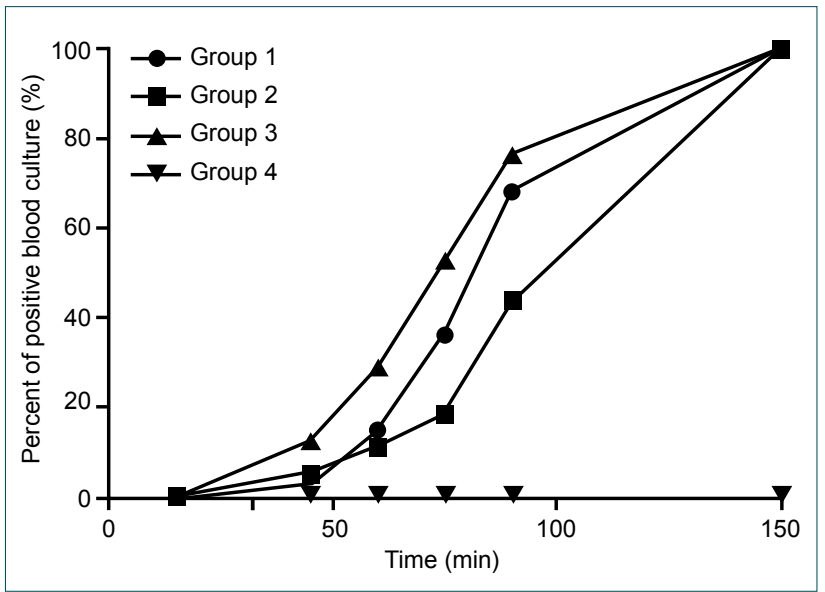

Figure 3. Kaplan-Meier curve showing percentage of positive blood cultures according to time. Group 1: Pressure group; Group 2: time group; Group 3: modified sigh group; Group 4: control group.

In addition, MAP was monitored continuously throughout the experiment, though only 6 MAP values for each rat were included in statistical analysis. Compared to baseline values, MAP had decreased in all groups by the end of the experiment. These decreases were statistically significant in Groups $\mathrm{I}, 2$, and 3 , but not in the control group.

A total of $4 \mathrm{~mL}$ blood was obtained for blood gas analyses and blood cultures throughout the study, and the same amount of colloid was used to replace blood loss. The amounts of $\mathrm{NaCl}$ used during the study period were $4.9 \pm 1.6 \mathrm{~mL}$ in Group I,

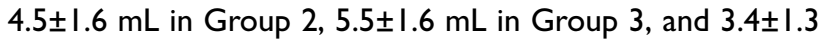
$\mathrm{mL}$ in Group 4.

Wet:dry weight ratio was higher in Group 3 (5.3 \pm 0.7$)$, com-

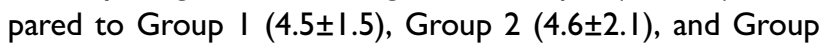
$4(4.6 \pm 0.3)$, though the differences were not statistically significant.

\section{Histology Results}

The right lung was evaluated for 6 pathological changes (Table $3)$. One of the most striking results was that the highest scores were seen in Group 3. Intra-alveolar hemorrhage, intra-alveolar macrophage, and polymorphonuclear leukocyte infiltration were significantly different among the groups $(p<0.05)$.

\section{DISCUSSION}

Primary findings were as follows:

I. RMs had positive blood cultures.

2. Modified sigh had negative effect on bacterial translocation, histopathology, and oxygenation.

Investigated in the present study were the influences of different RMs with the same inflation pressure-time product on bacterial translocation from the lungs to the bloodstream, and the modified sigh group was found to be at highest risk. Many experimental studies have shown that bacteria translocate from the lungs to the bloodstream via mechanical ventilation. ${ }^{[7-10]}$ Mechanical ventilation strategies associated with high VT and high airway pressure can produce microvascular injury in the lungs, leading to pulmonary edema, which results in lymphatic flow acceleration that allows bacteria to enter systemic circulation. ${ }^{[13,14]}$ Deterioration of mucociliary activity caused by mechanical ventilation can also facilitate passage of bacteria by disrupting bacterial clearance. The bacteria may be forced to spread out of the airway due to the physical impact of positive pressure, which is reported to be more significant in small animals. ${ }^{[1]}$

The highest rate of bacterial translocation via repeated RMs was observed in the modified sigh group. This rate, observed particularly in the early stages, indicated that repetitive opening and closing can cause more severe lung injury than exposure to high pressure or prolonged exposure to pressure. In an experimental study, Tschumperlin et al. demonstrated that repeated intermittent distention in alveolar cell culture leads to more inflammatory mediator secretion than fixed continuous distension. ${ }^{[15]}$ During histopathologic examination in the present study, intra-alveolar hemorrhage and intra-alveolar macrophage infiltration were found to be more significant in the modified sigh group. Though not statistically significant, other histopathologic parameters indicating lung injury were also found to be higher in the modified sigh group.

Table 3. Quantitative pathology scores of groups

\begin{tabular}{lccccc}
\hline & Group I & Group 2 & Group 3 & Group 4 & p \\
\hline Perivascular edema & $0.33 \pm 0.50$ & $0.50 \pm 0.70$ & $0.80 \pm 0.78$ & $0.25 \pm 0.50$ & 0.44 \\
Peribronchial lymphocyte infiltration & $1.55 \pm 1.01$ & $1.40 \pm 0.69$ & $2.00 \pm 0.66$ & $0.75 \pm 0.50$ & 0.06 \\
Intra-alveolar hemorrhage & $0.88 \pm 0.33$ & $1.10 \pm 0.73$ & $1.60 \pm 0.84$ & $0.50 \pm 0.57^{\dagger}$ & 0.04 \\
Intra-alveolar macrophage & $0.33 \pm 0.70^{*}$ & $0.60 \pm 0.69$ & $1.50 \pm 0.84$ & $0.50 \pm 1.00^{*}$ & 0.02 \\
Interstitial mononuclear cell infiltration & $2.00 \pm 0.86$ & $2.20 \pm 0.91$ & $2.30 \pm 0.67$ & $1.00 \pm 0.00^{\dagger}$ & 0.052 \\
Interstitial PNL infiltration & $1.55 \pm 1.01$ & $1.80 \pm 0.78$ & $2.40 \pm 0.69$ & $1.00 \pm 0.81^{\dagger}$ & 0.048 \\
Total & $1.11 \pm 0.98^{\alpha}$ & $1.26 \pm 0.95^{\alpha}$ & $1.76 \pm 0.90$ & $0.66 \pm 0.63^{\alpha}$ & $<0.0001$ \\
\hline
\end{tabular}

PNL: Polymorphonuclear leukocytes; " $\mathrm{p}<0.05$, significantly different from Group $3 ;{ }^{\alpha} \mathrm{p}<0.000$ I, significantly different from Group 3 ; ${ }^{\dagger} \mathrm{p}<0.05$, significantly different from Group 3 . 
In the 3 experimental groups, different numbers of positive blood cultures were observed after the first maneuver. This early bacteremia supports the hypothesis that application of mechanical ventilation can cause susceptibility to bacteremia. Lin et al. similarly reported that translocation of the instilled bacteria can lead to positive blood culture in spite of preventive artificial ventilation strategies $\left(\mathrm{V}_{\mathrm{T}}: 7 \mathrm{~mL} / \mathrm{kg}\right.$; PEEP: 5 $\left.\mathrm{cmH}_{2} \mathrm{O}\right) \cdot{ }^{\left[{ }^{16]}\right.}$ As mentioned in the methodology of the present study, there was an interval of I hour between the initiation of mechanical ventilation and sampling of the first positive blood culture. This interval apparently provided the necessary time for translocation.

In a previous study conducted by the present study group, an RM (45 $\mathrm{cmH}_{2} \mathrm{O} / 30 \mathrm{sec}$ ) had been applied every 15 minutes for 2 hours on rats that had been administered intratracheal Pseudomonas aeruginosa, and positive blood culture was not detected. ${ }^{[9]}$ However, in the present study, the rats were administered mechanical ventilation for 45 minutes prior to the first RM. This interval may have allowed bacteria to spread across the alveoli. Due to several environmental factors, reduced bacterial lag time increasing the number of bacteria may also have played a role in the translocation. Another important difference is that mechanical ventilation frequency was 60 /minute, and decrease in $\mathrm{PaCO}_{2}$ values was observed at the end of the study, compared to the baseline values. Cakar et al. used mechanical ventilation with a frequency rate of 30/minute, and $\mathrm{PaCO}_{2}$ increased in the RM group. Stretch injury due to mechanical ventilation could have been avoided by hypercapnic acidosis, and no growth may have been noticed in blood cultures, a suspicion that has been supported in the literature. ${ }^{[17,18]} A$ third difference between previous studies and the present is that, despite fluid resuscitation, MAP decreased, compared to baseline, in all groups except for the control group by the end of the study. It is thought that hypotension due to impaired circulation and repetitive opening and closing may have made the modified sigh group more susceptible to lung injury.

That the highest rate of oxygenation deterioration, the earliest and most pronounced growth on blood culture, and the highest, though still not significant, wet:dry ratio were observed in the modified sigh group has led the authors to suspect that the mechanism somehow causes increased damage to lungs, in spite of inflation pressure-time product and baseline ventilation parameters being identical to those of the other RMs. Though the 3 experimental groups were exposed to high pressure for the same amount of time, the method was different. PIP of $40 \mathrm{cmH}_{2} \mathrm{O}$ and PEEP of $3 \mathrm{cmH}_{2} \mathrm{O}$ caused repetitive opening and closing in the modified sigh group for I minute. It is thought that, because high levels of pressure elicit opening, the repetitive opening and closing result in damage to the alveoli. While duration of exposure to high pressure was the same, a constant level of pressure was applied with no variation in the pressure and time groups. Compared to the time group, growth was observed earlier and in greater amounts in the pressure group, though there was no statistically significant difference. However, the literature supports that of these 2 important RM components, pressure has more impact than time. ${ }^{[19-21]}$

Many interesting points have been made in the "pressure vs time" debate. Pressure and time are primary factors in recruitment and derecruitment of the alveoli. Based on the mathematical model developed by Bates and Irwin, alveoli not only have critical opening and closing pressure, but duration of opening and closing changes in acutely injured lungs. ${ }^{[22]}$

Several limitations affected the present study. First, such differentiations between the time and the pressure groups were not made, because volumetric measurements were not taken. Second, results of $40 \mathrm{cmH}_{2} \mathrm{O} / 40 \mathrm{sec}$ and $20 \mathrm{cmH}_{2} \mathrm{O} / 20$ sec groups were not compared with $40 \mathrm{cmH}_{2} \mathrm{O} / 20$ sec and 20 $\mathrm{cmH}_{2} \mathrm{O} / 40 \mathrm{sec}$ groups. Third, the same maneuvers used in an ARDS model may have produced different results.

In conclusion, all RMs eventually resulted in bacteremia. Higher severity of VILI occurred in the modified sigh group, evidenced by bacterial translocation and histopathological evaluation, despite it having the same inflation pressure-time product as the other RM groups.

\section{Acknowledgments}

This study was performed in the experimental laboratory founded by Prof. Dr. Kutay AKPIR at İstanbul University's Department of Anesthesiology and Intensive Care. In addition, the authors thank Fatma Vildan Adali for assistance with all randomization procedures.

\section{Conflict of interest: None declared.}

\section{REFERENCES}

1. Dreyfuss D, Saumon G. Ventilator-induced lung injury: lessons from experimental studies. Am J Respir Crit Care Med 1998;157:294-323.

2. Kacmarek RM, Kallet RH. Respiratory controversies in the critical care setting. Should recruitment maneuvers be used in the management of ALI and ARDS? Respir Care 2007;52:62235.

3. Lapinsky SE, Aubin M, Mehta S, Boiteau P, Slutsky AS. Safety and efficacy of a sustained inflation for alveolar recruitment in adults with respiratory failure. Intensive Care Med 1999;25:1297-301. CrossRef

4. Grasso S, Mascia L, Del Turco M, Malacarne P, Giunta F, Brochard L, et al. Effects of recruiting maneuvers in patients with acute respiratory distress syndrome ventilated with protective ventilatory strategy. Anesthesiology 2002;96:795-802. CrossRef

5. Barbas CSV, Silva E, Garrido A, Assunção M, Hoelz C, Meyer EC, et al. Recruitment maneuvers with different pressure control levels inARDS patients (abstract). Am J Respir Crit Care Med 2001;163:767.

6. Constantin JM, Jaber S, Futier E, Cayot-Constantin S, Verny-Pic M, Jung B, et al. Respiratory effects of different recruitment maneuvers in acute respiratory distress syndrome. Crit Care 2008;12:50. CrossRef

7. Nahum A, Hoyt J, Schmitz L, Moody J, Shapiro R, Marini JJ. Effect of mechanical ventilation strategy on dissemination of intratracheally instilled Escherichia coli in dogs. Crit Care Med 1997;25:1733-43. CrossRef 
8. Verbrugge SJ, Sorm V, van't Veen A, Mouton JW, Gommers D, Lachmann B. Lung over inflation without positive end-expiratory pressure promotes bacteremia after experimental Klebsiella pneumoniae inoculation. Intensive Care Med 1998;24:172-7. CrossRef

9. Cakar N, Akinci O, Tugrul S, Ozcan PE, Esen F, Eraksoy H, et al. Recruitment maneuver: does it promote bacterial translocation? Crit Care Med 2002;30:2103-6. CrossRef

10. Ozcan PE, Cakar N, Tugrul S, Akinci O, Cagatay A, Yilmazbayhan D, et al. The effects of airway pressure and inspiratory time on bacterial translocation. Anesth Analg 2007;104:391-6. CrossRef

11. Tremblay L, Valenza F, Ribeiro SP, Li J, Slutsky AS. Injurious ventilatory strategies increase cytokines and c-fos m-RNA expression in an isolated rat lung model. J Clin Invest 1997;99:944-52. CrossRef

12. Amato MB, Barbas CS, Medeiros DM, Magaldi RB, Schettino GP, Lorenzi-Filho $\mathrm{G}$, et al. Effect of a protective-ventilation strategy on mortality in the acute respiratory distress syndrome. N Engl J Med 1998;338:34754. CrossRef

13. Dreyfuss D, Soler P, Saumon G. Mechanical ventilation-induced pulmonary edema. Interaction with previous lung alterations. Am J Respir Crit Care Med 1995;151:1568-75. CrossRef

14. Brigham KL. Mechanisms of lung injury. Clin Chest Med 1982;3:9-24.

15. Tschumperlin DJ, Oswari J, Margulies AS. Deformation-induced injury of alveolar epithelial cells. Effect of frequency, duration, and amplitude. Am J Respir Crit Care Med 2000;162(2 Pt 1):357-62. CrossRef

16. Lin CY, Zhang H, Cheng KC, Slutsky AS. Mechanical ventilation may increase susceptibility to the development of bacteremia. Crit Care Med 2003;31:1429-34. CrossRef

17. Contreras M, Ansari B, Curley G, Higgins BD, Hassett P, O'Toole D, et al. Hypercapnic acidosis attenuates ventilation-induced lung injury by a nuclear factor- $\mathrm{KB}$-dependent mechanism. Crit Care Med 2012;40:262230. CrossRef

18. Ni Chonghaile M, Higgins BD, Costello JF, Laffey JG. Hypercapnic acidosis attenuates severe acute bacterial pneumonia-induced lung injury by a neutrophil-independent mechanism. Crit Care Med 2008;36:3135-44.

19. Albert SP, DiRocco J, Allen GB, Bates JH, Lafollette R, Kubiak BD, et al. The role of time and pressure on alveolar recruitment. J Appl Physiol (1985) 2009;106:757-65. CrossRef

20. Arnal JM, Paquet J, Wysocki M, Demory D, Donati S, Granier I, et al. Optimal duration of a sustained inflation recruitment maneuver in ARDS patients. Intensive Care Med 2011;37:1588-94. CrossRef

21. Marini JJ. Recruitment by sustained inflation: time for a change. Intensive Care Med 2011;37:1572-4. CrossRef

22. Bates JH, Irvin CG. Time dependence of recruitment and derecruitment in the lung: a theoretical model. J Appl Physiol (1985) 2002;93:705-13.

\title{
DENEYSEL ÇALIŞMA - ÖZET
}

\section{Farklı yeniden kazandırma manevralarının bakteri translokasyonu ve ventilatör ilişkili akciğer hasarına etkisi \\ Dr. Perihan Ergin Özcan, ${ }^{1}$ Dr. Özkan İbrahim Akıncı, ${ }^{1}$ Dr. Ipek Edipoğlu, ${ }^{1}$ Dr. Evren Şentürk, ${ }^{1}$ Dr. Sevil Baylan, Dr. Atahan Arif Çağatay, ${ }^{2}$ Dr. Kemal H Türköz, ${ }^{3}$ Dr. Figen Esen, ${ }^{1}$ Dr. Lütfi Telci, ${ }^{1}$ Dr. Nahit Çakar ${ }^{1}$}

\author{
'İstanbul Üniversitesi İstanbul Tıp Fakültesi, Anesteziyoloji Anabilim Dalı, İstanbu \\ ${ }^{2}$ İstanbul Üniversitesi İstanbul Tıp Fakültesi, İnfeksiyon Hastalıkları ve Klinik Mikrobiyoloji Anabilim Dalı, İstanbul \\ ${ }^{3}$ Marmara Üniversitesi Tıp Fakültesi, Patoloji Anabilim Dalı, İstanbul
}

AMAÇ: Bu çalışmada, aynı basınç-zaman ürünlü farklı yeniden kazandırma manevralarııı akciğerden kana bakteri geçişine ve ventilatör ilişkili akciğer hasarına etkisi araştıııldı.

GEREÇ VE YÖNTEM: Sıçanlara anestezi uygulandıktan sonra trakeotomi açıldı ve basınç kontrollü ventilasyon modunda ventilasyona başlandı. Ardından Pseudomonas aeruginosa içeren solüsyon trakeotomi kanulünden verilip, ventilasyona bu şekilde 30 dakika devam edildikten sonra sıçanlar rastgele dört gruba ayrıldı. Grup I: "Sustained inflation” (SI); Grup 2: Düşük basınç SI (LPSI); Grup 3: Modifiye Sigh; Grup 4: Kontrol grubu. Kan kültürleri bakteri verilmeden önce, ilk bir saat her yeniden kazandırma manevrasından sonra ve son manevradan 75 dakika sonra olmak üzere toplam altı kez alındı. Daha sonra sıçanlar arter içine verilen sodium tiyopental ile sakrifiye edilerek toraks açııp akciğerler çıkarıldı. Sol akciğer yaş kuru ağırık (WW/DW) oranı için, sağ akciğer patolojik inceleme için kullanıldı.

BULGULAR: Kan kültürlerine bakıldığında Grup 3 de daha erken dönemde kan kültürlerinde üreme tespit edildi. Grup 3'de patolojik skorlar daha yüksek bulundu.

TARTIŞMA: Bakteriyel translokasyon ve histopatolojik değerlendirmelerle modifiye Sigh ile daha ciddi ventilatör ilişkili akciğer hasarı oluşmuştur. Anahtar sözcükler: Bakteriyel translokasyon; mekanik ventilasyon; sign; ventilator ilişkili akciğer hasarı; yeniden kazandırma manevrası.

Ulus Travma Acil Cerrahi Derg 2016;22(2):127-133 doi: 10.5505/tjtes.20I5.05406 